\title{
THE MILLIPEDE GENUS CYLINDROIULUS VERHOEFF, 1894 IN NORTH-WEST SPAIN AND NORTHERN PORTUGAL: RECENT RECORDS AND DESCRIPTIONS OF FOUR NEW SPECIES (DIPLOPODA, JULIDA, JULIDAE)
}

\author{
H. J. Read*
}

\begin{abstract}
Recent collections of millipedes from north-west Spain and northern Portugal have yielded 11 species of the genus Cylindroiulus. Four species are described as new $(C$. anglilectus, $C$. boreoibericus, $C$. gregoryi, $C$. ventanaea), three species are new to Spain -C. britannicus (Verhoeff, 1891), C. fenestratus Read, 1989, C. dahli Demange, 1970and two are recorded for the Iberian mainland for the first time having previously been found on the Atlantic islands: C. truncorum (Silvestri, 1896) in Portugal and C. dahli in Spain. Notes are given on the relationship between the new species and those previously described, including those endemic to the Madeiran archipelago. A key to species likely to be found in the northwest of the Iberian pensinsula is presented.
\end{abstract}

Key words: Cylindroiulus, millipede, new species, Spain, Portugal, anglilectus, boreoibericus, gregoryi, ventanaea

\section{RESUMEN}

El género de miriápodos Cylindroiulus Verhoeff, 1894 en el noroeste de España y el norte de Portugal: Citas recientes y descripción de cuatro nuevas especies (Diplopoda, Julida, Julidae)

Recientes recolecciones de miriápodos del noroeste de España y norte de Portugal han permitido obtener 11 especies del género Cylindroiulus. Se describen cuatro nuevas especies ( $C$. anglilectus, $C$. boreoibericus, $C$. gregoryi, $C$. ventanaea), tres nuevas citas para España -C. britannicus (Verhoeff, 1891), C. fenestratus Read, 1989, C. dahli Demange, 1970-, y dos especies son citadas por primera vez en la Península Ibérica, tras haber sido previamente descritas en islas atlánticas: $C$. truncorum (Silvestre, 1896) en Portugal y $C$. dahli en España. Se incluyen notas sobre relaciones de las especies nuevas con otras previamente descritas, incluidas algunas endémicas del archipiélago de Madeira. Se presenta una clave de especies de probable aparición en el noroeste de la Peninsula Iberica.

Palabras clave: Cylindroiulus, milpiés, especies nuevas, España, Portugal, anglilectus, boreoibericus, gregoryi, ventanaea.

* The Natural History Museum, Cromwell Road, London SW7 5BD, U.K.

Address for correspondence: 2 Egypt Wood Cottages, Egypt Lane, Farnham Common, Bucks. SL2 3LE, U.K. E-mail: helen.read@dsl.pipex.com 


\section{Introduction}

The European genus Cylindroiulus Verhoeff, 1894, is one of the largest in the family Julidae containing over 100 species, some with restricted distributions (although individuals may be very abundant) and others such as Cylindroiulus latestriatus (Curtis, 1845) that have spread across the globe. Verhoeff (1930) attempted to provide some structure to this large group of species by recognising three genera and 14 subgenera in the tribe Cylindroiulini. The genus Cylindroiulus and its relationship with other genera in the tribe was redefined and clarified by Read (1990) but this did not include comments on relationships between species within the newly defined genus. A large number of subgenera and species groups have been proposed over the years, however there has not yet been a full evaluation of their validity or relationships. Despite this some of the older subgeneric names are useful for referring to groups of individual species and in addition, taxonomic work has broken some of these subgenera down further for practical reasons. Thus progress has been made with this genus by treating discrete species groups as units (Korsós \& Enghoff, 1990, Read, 1992, Read, 2005 etc.) and/or examining those from geographic areas (Enghoff, 1982). A considerable number of species from southern Europe still require detailed evaluation.

During a recent collecting trip to north west Spain and northern Portugal by the British Myriapod \& Isopod Group in Spring 2004 (Lee 2004) several new species were discovered (see also Mauriès 2005), including some from the genus Cylindroiulus. The focus of the collections was southern Galicia (Spain) and the northern part of Viana do Castelo (Portugal). This collection is augmented by samples collected by D. Bilton in the same area a few years previously, also including a few from Asturias (Spain) and also some collected by Desmond Kime.

ACRONYMS OF REPOSITORIES AND ABBREVIATIONS USED IN THE TEXT

Specimens of newly described species have been deposited in the following places: MNCN - Museo Nacional de Ciencias Naturales, Madrid, Spain; MNP - Muséum National d'Histoire Naturelle, Paris, France; BMNH - The Natural History Museum, London, U.K.; SGMT - Sheffield Galleries \& Museum, Sheffield, U.K.; ZMUC - Zoologisk Museum, Københavns Universitet, Denmark.
The collectors of the specimens are as follows: DB - David Bilton; DK - R. Desmond Kime; HR - Helen Read; JL - John Lewis; JPR - J. Paul Richards; PL - Paul Lee; SG - Steve Gregory.

The following abbreviations are used in the text: $\mathrm{H}$ - maximum body height ( $\mathrm{mm}$ ); $\mathrm{L}$ - Body length from head to anal valves, not including telson projection (if any); Body rings given as podous body rings + apodous body rings (not including telson). Measurements were made following the techniques of Enghoff (1982), with body length measured at ozopore level and body height being the maximum not including legs, both measured using a dissecting microscope. Leg measurements were made by removing a mid body leg and making a temporary slide. Total leg length is the sum of the podomere lengths including the claw but not the coax or trochanter.

Abbreviations on the figs are as follows: $\mathrm{A}-$ anterior; B - brachite; $\mathrm{F}$ - flagellum; $\mathrm{K}$ - keel; $\mathrm{M}$ mesomerite; $\mathrm{P}$ - promerite; the numbers refer to body rings.

\section{Systematics of the millipede genus Cylindroiulus}

\section{DEFINITION OF THE GENUS CYLINDROIULUS}

Cylindroiulus are small to medium sized subcylindrical julids, usually with some degree of pigmentation, lacking setae on the metazonites and also any frontal setae. The male gonopods are variable but the flagellum is always present (although it may be reduced in length) and the mesomerite single. The stipetes of mature males are expanded. There is considerable variation in telson shape, and the number of ocelli can vary between almost complete complement and total absence.

\section{Cylindroiulus Subgenus Aneuloboiulus VerhoefF, 1899}

The subgenus Aneuloboiulus is the most species rich and widely distributed, including widely distributed species such as $C$. latestriatus, $C$. britannicus (Verhoeff, 1891) and C. truncorum (Silvestri, 1896). However Enghoff (1982) points out that it is characterised by plesiomorphic traits and in the keys to subgenera in Attems (1927) and Verhoeff (1930) it is the last to key out, defined generally by a lack of obvious features. Species are generally small, showing the basic Cylindroiulus colour pattern where the head is mostly light with darker markings, usually a band between the eyes and along 
the posterior margin, especially mid dorsally. The body is also pale to mid brown with darker areas ventral to the ozopores and dorsally. The collum, telson area and segments of antennae and legs are also generally pale to mid brown with darker margins. The telson shape is variable as are the number of setae on the anal valves. The male gonopods are generally 'typical' Cylindroiulus shape, with simple and well defined pro-, meso- and opisthomerites. The paracoxal process is present and the paracoxal rim present, but variable in strength.

Some species within the subgenus Aneuloboiulus have been studied recently and it has proved convenient to distinguish species groups, for example the madeirae Attems, 1937 group (Enghoff 1982, Read, 1989a), the truncorum group (Korsós \& Enghoff 1990), and the perforatus group (Read, 1989b). In addition, Blower (1985) referred to the luscus Meinert, 1868 group, meaning latestriatus, britannicus, punctatus (Leach, 1815) and those species in the truncorum group, here the latestriatus group has been used as a more restricted term to describe latestriatus, britannicus and related species. The remaining bulk of the species have yet to be studied systematically. Species listed in the present study can be referred to the latestriatus group, the perforatus Verhoeff, 1905 group, the truncorum group and some to Cylindroiulus generally, pending further study.

THE GENUS CYLINDROIULUS IN IBERIA

Attems (1927) listed just three Cylindroiulus species from northern and eastern Spain, however prior to the current fieldwork a total 16 species of Cylindroiulus had been recorded from mainland Iberia (Enghoff \& Kime, 2004) although many more have been described from the Spanish and Portuguese Atlantic islands. Note that Allajulus spinosus (Ribaut, 1904) is also listed in many publications as a species of Cylindroiulus. Of the mainland species, seven have been found from the Spanish Pyrenees and the other nine from scattered locations. The best studied part of the Iberian peninsular is probably Cataluna (Vicente, 1985). Appendix 1 lists all species from Iberia, including those reported here.

\section{Species finds and descriptions}

\section{The Cylindroiulus latestriatus group}

This species group is characterised by three pairs of setae on the anal valves and gonopods that vary little between the species. Blower (1985) also mentions the widely spaced metazonite striae.

\section{Cylindroiulus latestriatus (Curtis, 1845)}

PORTUGAL: Vila Praia de Âncora, Viana do Castelo.

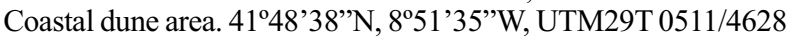
(NG12), 27.3.04. 1M, 4F (JPR).

SPAIN: A Coruna, Praia Riocobo, S of Punta Roncudo shore. UTM29T(NH09), 27.ii.1993. 2M, 2F (DB).

Santander, Liencres. Pinewood on edge of coastal dunes. UTM30T(VP21), 2.5.99. 4M, 3F (DK).

This widespread species has been previously recorded from some coastal localities in northern Spain and Portugal (Kime, 1999) as well as the Canary Islands.

\section{Cylindroiulus britannicus (Verhoeff, 1891)}

SPAIN: As Eiras, Pontevedra. Alder wood. 4156'03'N, 846'06"W, UTM 29T (NG14), 25.3.04. 7M, 32F/J (HJR), 7M, $6 \mathrm{~F}$ (DK), 5M, 21F/j (SG).

Goián, Pontevedra, N bank of Rio Miño, near beach. UTM 29T 0520/4643, (NG24), 25.3.04. 1M, 4F (JPR), 1M, 6F (HJR). Between As Eiras \& Goián, Pontevedra. Inshore island, Rio Miño, 41 ${ }^{\circ} 55^{\prime} 54$ ”'N, 846’04”W, UTM29T 0519/4642 (NG14), 25.3.04. 1M, 3F (SG)

A Coruña, A Capela Caaveiro, Quercus wood, UTM29T(NJ70), 13.ii.1993. (DB) (See note below)

PORTUGAL: Vila Praia de Âncora, Viana do Castelo. Coastal dune area. $41^{\circ} 48^{\prime} 38^{\prime \prime} \mathrm{N}, 8^{\circ} 51^{\prime} 35^{\prime \prime} \mathrm{W}$, UTM29T 0511/4628 (NG12), 27.3.04. 3M, 2F, 10F/j (SG).

This species has been recorded from Portugal, Madeira and the Azores but not previously from mainland Spain (Kime, 1999). However there is now another reported find from closer to Madrid (Kime pers. comm., 2007).

\section{Cylindroiulus boreoibericus sp. n. (Figs. 1-5)}

TYPe material: Holotype: 1M PORTUGAL: Vila Praia de Âncora, Viana do Castelo. Coastal dune area. $41^{\circ} 48^{\prime} 38^{\prime \prime} \mathrm{N}$, 8०51'35"W, UTM29T 0511/4628 (NG12), 27.3.04. (HR) (BMNH).

Paratypes: $1 \mathrm{M}, 8 \mathrm{~F}, 1 \mathrm{jM}$ details as above. (HR) (1M, $4 \mathrm{~F}$ MNCN; 4F1jM BMNH).

OTHER MATERIAL: 1M, 4F SPAIN: A Coruña, a Capela Caaveiro. Quercus wood. UTM29T(NJ70), 13.ii.1993. (DB) (ZMUC).

Diagnosis: A medium sized species very similar to $C$. britannicus but differing in the presence of a large pointed telson projection and more body rings per stadium. Mesomerite of gonopods narrow, opisthomerite thin in posterior view, always with hook shaped brachite curved strongly anteriorly. 

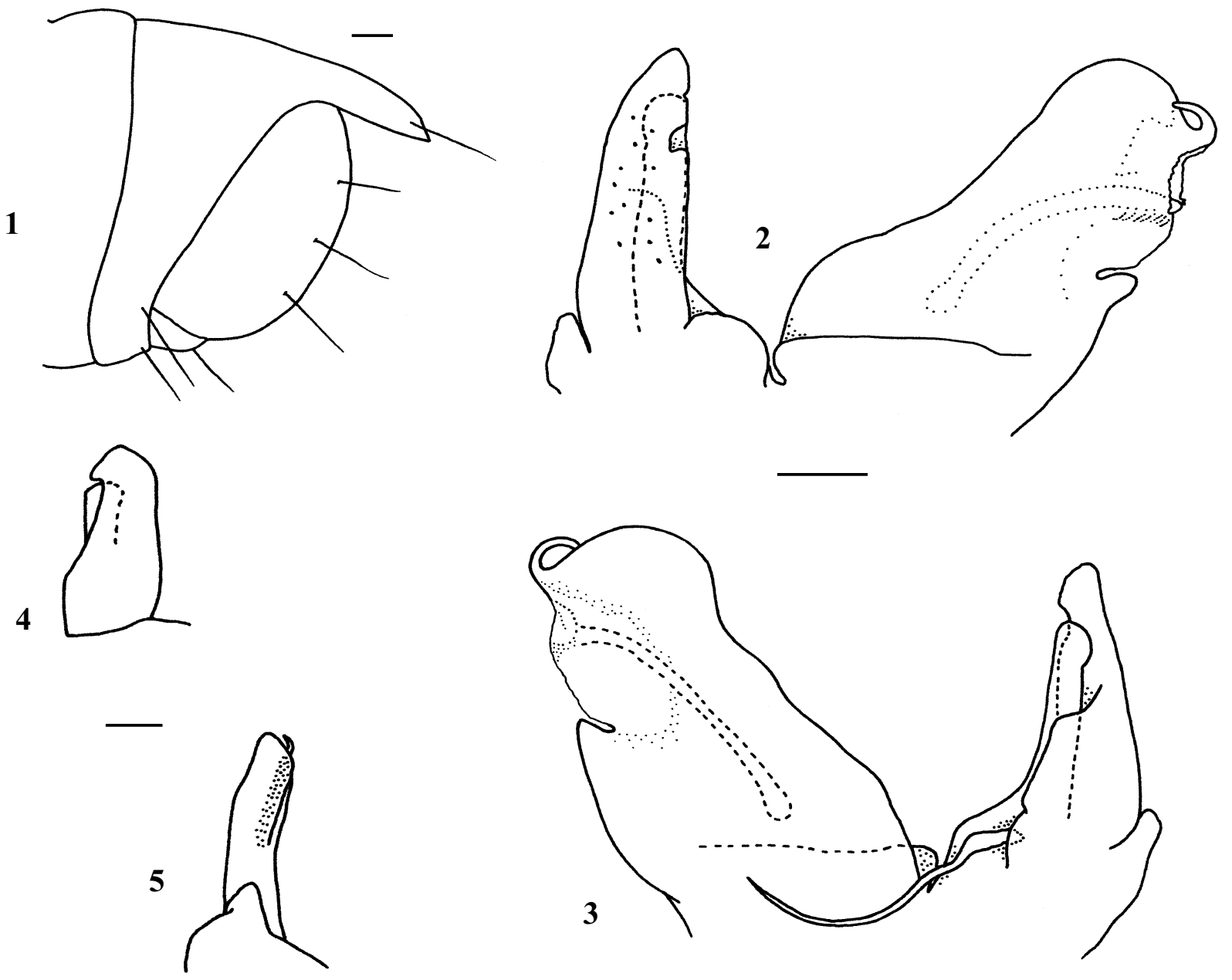

Figs. 1-5.- Cylindroiulus boreoibericus, holotype male (all scale bars $=0.1 \mathrm{~mm}$ ). 1) Telson and anal valves. 2) Right gonopods lateral view. 3) Right gonopods mesal view. 4) Right gonopods anterior view. 5) Right gonopods posterior view.

Figs. 1-5.-Cylindroiulus boreoibericus, holotipo macho (barras de escala $=0,1 \mathrm{~mm}$ ). 1) Telson y valvas anales. 2) Vista lateral del gonópodo derecho. 3) Vista mesal del gonópodo derecho. 4) Vista anterior del gonópodo derecho. 5) Vista posterior del gonópodo derecho.

DESCRIPTION: Holotype M: Length unmeasurable, body too twisted, $\mathrm{H}$ (maximum): $1.1 \mathrm{~mm}, 7$ rows of ocelli (= stadium VIII), 43+3 (+ telson) body rings.

Paratype male: Length unmeasurable, $\mathrm{H}$ (max): $1.1 \mathrm{~mm}, 7$ rows of ocelli (= stadium VIII) $43+5$ (+telson) body rings.

Paratype females: Length to $19 \mathrm{~mm}, \mathrm{H}(\max )$ : 1.5 , maximum 7 rows of ocelli (= stadium VIII), 45 podous body rings.
Paratype jM: Length unmeasurable, $\mathrm{H}$ (max): $0.8 \mathrm{~mm}, 4$ rows of ocelli (= stadium $\mathrm{V}), 24+(? 4)$ body rings.

Other male: Length and $\mathrm{H}$ unmeasurable, 9 rows of ocelli (= stadium X), unknown number of body rings.

Other females: Length to maximum of $22 \mathrm{~mm}, \mathrm{H}$ (max) to $1.7 \mathrm{~mm}$, up to 8 rows of ocelli (= IX), up to $48+2$ body rings. 
Body colour basic Cylindroiulus pattern but those from the type locality markedly paler ventrally especially posteriorly. Metazonal striae close and regular. Vaulting almost absent, anterior constriction very slight; attenuation only of apodous rings. Legs pale, almost white (in alcohol), antennae with some pigment. Animals from type collection all show purple tinges in the head (especially the mandibular stipetes) and telson region. It is not known if this is an artefact of preservation but was not noticed in specimens of other species collected and stored in the same way. Ocelli in regular rows.

Length of legs $0.64 \mathrm{x}$ body height. Tarsus $\mathrm{L} / \mathrm{H}$ : 3.2. Length of claw 0.07 of total leg. Accessory claw surpassing claw by $16 \%$.

Preanal ring with strong projection clearly surpassing the anal valves, very pointed at apex, with 1 pair of setae on the projection, one pair ventrally and one pair lateroventrally. Subanal scale with one pair of setae, anal valves with three pairs (Fig. 1).

Mandibular stipetes of mature males smoothly expanded but not greatly so. First pair of legs small hooks.

Gonopods (Figs. 2-5). Length $0.87 \mathrm{x}$ body height.

Promerite slightly longer than mesomerite, hooked apically and with large flange mesally. Flagellum reduced in length and more wiggly than typical close to point of insertion (also in male from Spanish collection). Mesomerite thin and slightly hooked apically. Pointed paracoxal process clearly separate from opisthomerite although very close. Opisthomerite very similar to some illustrations of C. britannicus. With small apical brachite curled anteriorly and clear region close to entrance of sperm canal. Opisthomerite thin and plate-like (most obviously visible in ventral view).

ETYMOLOGY: The name reflects the current known distribution of this species in the northern part of the Iberian peninsula.

RELATIONSHIPS WITH OTHER SPECIES: Cylindroiulus boreoibericus is clearly very similar to $C$. britannicus and initially was considered an aberrant form with a strong telson projection. However the shape of the telson has previously proved a reliable character for determining species in the genus; this is the first species in the latestriatus group with a large telson projection. C. boreoibericus does however differ in other respects too. The pro- and mesomerite are more slender and slightly different shapes, with the promerite clearly hook-shaped apically, the flagellum is reduced in length and the paracoxal process is clearly separated from the opisthomerite.
According to the dimensions of $C$. britannicus in Blower (1985) the specimens here are slightly larger (especially those from Spain) and they differ in the number of podous rings per stadium as listed below:

$\begin{array}{lcc}\text { Stadium } & \text { britannicus (Blower, 1985) } & \begin{array}{c}\text { boreoibericus } \\ \text { V }\end{array} \\ \text { VIII } & 36-25 \text { podous rings } & 17-24 \text { podous rings } \\ \text { VII } & 39-42 & 41-45 \\ \text { IX } & 41-43 & 47-48 \\ \text { X } & & 48\end{array}$

Note that specimens of $C$. britannicus were also found from the type locality for $C$. boreoibericus. Those examined conformed to the ring numbers expected for the species according to Blower (1985).

Cylindroiulus gregoryi sp. n. (Figs. 6-11)

TyPe Material: Holotype: 1M SPAIN: Finca Rio Mino. 25.iii.2004. S. Gregory leg. (BMNH).

Paratypes: 5M, 5F, 3jM details as above. (1F, $1 \mathrm{jM}$ BMNH; 1M, 1F MNCN; 2M, 2F ZMUC; 1M, 1F MNP; 1M SGM).

Diagnosis: A medium to small, blind species. With a pointed but not projecting telson projection, short and triangular shaped pro- and mesomerites and an opisthomerite with a single large apical projection.

DESCRIPTION: Holotype M: Length $13 \mathrm{~mm}, \mathrm{H}$ (maximum): 0.9, L/H: 14, no ocelli, 37+2 (+ telson) body rings.

Paratype males: Length $12-15 \mathrm{~mm}, \mathrm{H}$ (Max): 0.8-0.9 mm, no ocelli, 32-40 podous body rings.

Paratype females: Maximum length: $16 \mathrm{~mm}$, maximum $\mathrm{H}(\max )$ : $1.07 \mathrm{~mm}$, up to 43 podous body rings.

Body pale grey brown (in alcohol). Head and anterior rings straw/ginger brown, main trunk more grey. Prozonites slightly darker. Slight anterior constriction at rings 5-6, attenuation only of apodous rings. Legs and antennae pale brown, as body, also preanal ring and anal valves.

Ocelli completely lacking (Fig. 6).

Metazonal striae clear and well spaced, vaulting present in mid body rings. Ozodenes dark and blackish.

Length of legs $0.4 \mathrm{x}$ body height. Tarsus $\mathrm{L} / \mathrm{H}$ : 3.2. Length of claw 0.19 of total leg. Accessory claw falling short of claw by $28 \%$.

Preanal ring reaching an obvious point but not projecting beyond the anal valves. With one pair of setae arising from the projection, one pair ventrally and usually three pairs laterally. Anal valves with 3 or 4 pairs of setae (Fig. 7). 


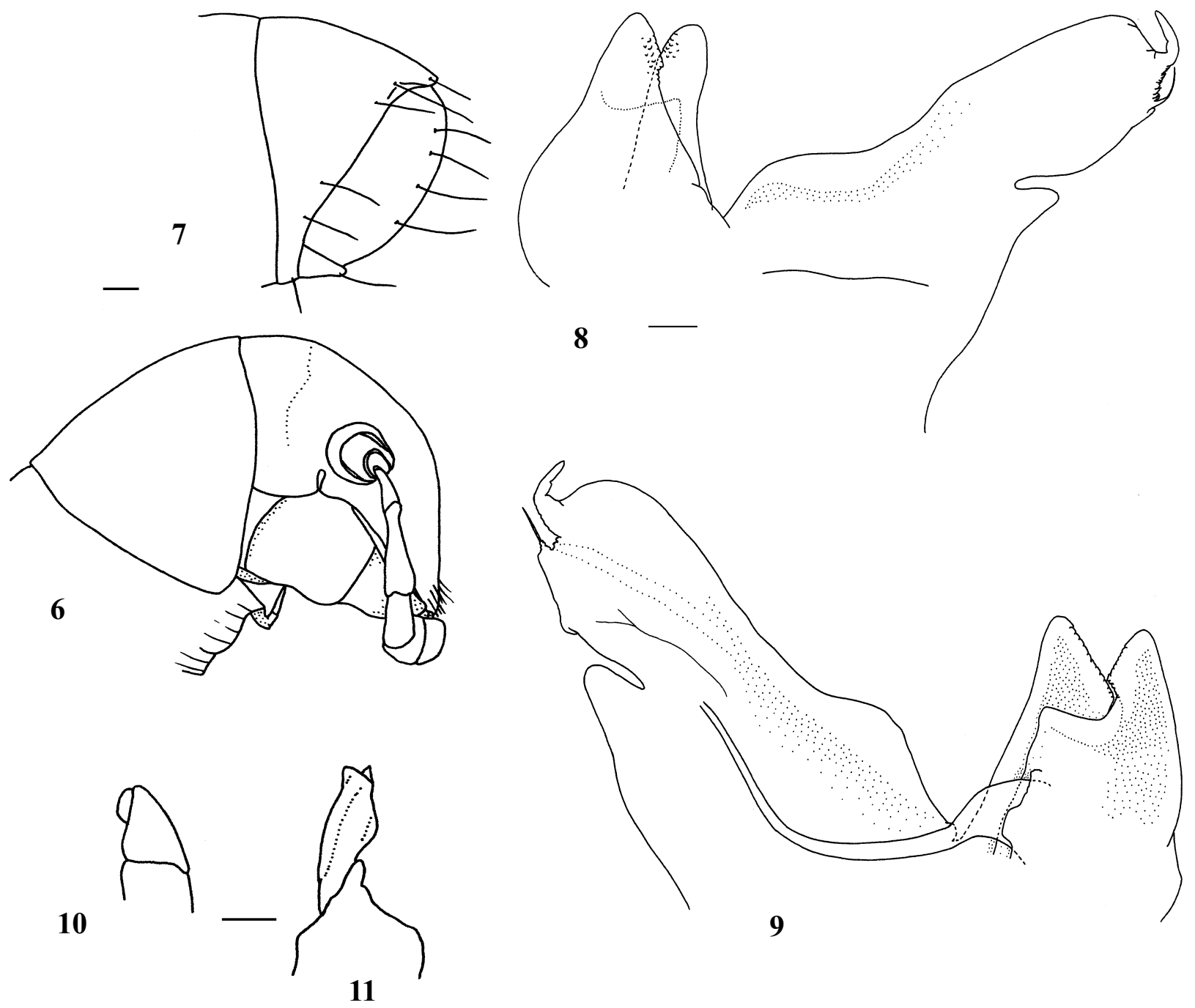

Figs. 6-11.-Cylindroiulus gregoryi, holotype male. 6) Head showing lack of ocelli. 7) Telson and anal valves. 8) Right gonopods lateral view. 9) Right gonopods mesal view. 10) Right gonopods anterior view. 11) Right gonopods posterior view. Scale bar of $6,7,10$ and $11=0.1 \mathrm{~mm} ; 8$ and $9=0.04 \mathrm{~mm}$.

Figs. 6-11.-Cylindroiulus gregoryi, holotipo macho. 6) Cabeza mostrando falta de ocelos. 7) Telson y valvas anales. 8) Vista lateral del gonópodo derecho. 9) Vista mesal del gonópodo derecho. 10) Vista anterior del gonópodo derecho. 11) Vista posterior del gonópodo derecho: Barra de escala de 6, 7, 10 y $11=0,1 \mathrm{~mm} ; 8$ y $9=0.04 \mathrm{~mm}$.

Mandibular stipetes of mature males smoothly expanded but not greatly so. First pair of legs sharp hooks.

Gonopods (Figs. 8-11). Length $0.5 \mathrm{x}$ body height.

Promerite squat and triangular in shape. With lateral expansion mesally and normal flagellum.
Mesomerite also triangular in shape, just visible mesally in anterior view. Paracoxal rim low and poorly developed, paracoxal process simple. Opsithomerite broad apically, with prominent projection apically, directed anteriorly.

ETYMology: This species is named in recognition of Steve Gregory who not only found all the 
specimens but is a very talented collector of myriapods.

RELATIONSHIPS WITH OTHER SPECIES: The shape of the opisthomerite is reminiscent of $C$. britannicus, some specimens of which have the apical projection directed anteriorly, and C. boreoibericus. This species is clearly different from C. britannicus in the shapes of the pro- and mesomerite and also in the lack of ocelli. There is currently only one other valid blind Cylindroiulus, C. vulnerarius (Berlese, 1888) (of which C. ellingseni Verhoeff, 1912 is a synonym), however the gonopods of $C$. vulnerarius are quite different to those of $C$. gregoryi in possessing a large brachite and large, smoothly expanded region dorsal to the paracoxal process. Another blind but undescribed Cylindroiulus is known from a Madeiran cave (Enghoff, 1992). Like C. vulnerarius, C. gregoryi is rather pale and the typical Cylindroiulus colour pattern is poorly developed, it also has rather short legs, suggesting a soil dwelling habit.

\section{The $C$. perforatus group}

The two species currently in this group were described in detail by Read (1989b) and are characterised by a perforation or window in the promerite of the gonopods. Specimens were looked at in detail and whilst some have an obvious hole others have just a thin area which appears as a hole.

The recent collections have added five further sites for C. fenestratus Read, 1989 and two new species were also discovered. One found by D. Bilton at a single locality in northern Galicia which shows strong similarities with $C$. fenestratus and has a truly perforate promerite, and one more widespread in the southern area which has a 'window' in the promerite although appears not truly perforate.

\section{Cylindroiulus fenestratus Read, 1989}

SPAIN: Oia Harbour, Pontevedra, 42 00 '06'N, 8'52'37'W, UTM 29T 0510/4650 (NG15), 24.3.04. 1M, 1F (JPR) (SGM). Camposancos, nr. La Guardia (A Guarda), Pontevedra, 4153'43”N, 8051'55"W, UTM 29T 0511/4638 (NG13), 29.3.04. 1M, 1F (JRP) (MNP), 2M, 6F (HJR) (ZMUC).

Amorin, Pontevedra. Farmland, ditches \& woodland ver-

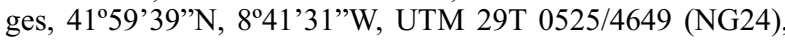
29.3.04. 3M, 5F (HJR) (MNCN), 1M (PL) (BMNH), 1M (SG) (ZMUC).

PORTUGAL: Vila Praia de Âncora, Viana do Castelo.

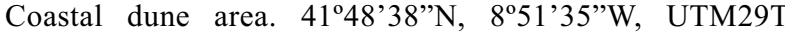
0511/4628 (NG12), 27.3.04. 1M (HR) (BMNH).
Caminho, Distrito de Viana do Castelo, Minho, coastal woods \& dunes 41 $51^{\prime} 02^{\prime \prime} \mathrm{N}, 8^{\circ} 51^{\prime} 20^{\prime \prime}$ 'W, UTM 29T 0512/4635 (NG13), 27.3.04. 1M (HJR) (MNCN).

Cylindroiulus fenestratus was described (Read 1989 b) from two specimens from a single locality in northern Portugal, thus these collections add four further sites and are also the first reports of this species from Spain. The animals conform to the original description, including details of the gonopods.

\section{Cylindroiulus ventanaea sp. n. (Figs. 12-17)}

TYPE MATERIAL: Holotype: 1M SPAIN: A Coruña, a Capela Caaveiro. Quercus wood. UTM29T(NJ70), 6.ii.1993. D. Bilton leg. (BMNH).

Paratype: $1 \mathrm{jM}$ details as above. (BMNH).

OTHER MATERIAL: 1M locality as above, 13.ii.1993. D. Bilton leg. $(\mathrm{MNCN})$.

Diagnosis: A medium sized Cylindroiulus species, slightly darker dorsally and lacking a telson projection. Promerite of gonopods truly perforate and extending round a very long mesomerite. Paracoxal process very large, with three large hook-like spikes and other protruberances. Accessory claw on the legs much longer than claw.

DESCRIPTION: Holotype M: Length: $21 \mathrm{~mm}, \mathrm{H}$ (maximum): $1.4 \mathrm{~mm}, \mathrm{~L} / \mathrm{H}: 15.4,9$ rows of ocelli (= stadium $\mathrm{X}$ ), $49+3$ (+ telson) body rings.

Paratype: jM: Length: 13 mm, H: 1.2, L/H: 11.7, 7 rows of ocelli (Stadium VIII), 40+5 ( + telson) body rings.

$\mathrm{M}$ from same locality (different date): Length: 26, H: 1.4, L/H: 19, 9-10 rows of ocelli (last row(s) jumbled), $51+2$ (+ telson) body rings.

Generally pale brown in colour. Darker dorsally and pro- and metazonites differing in colour to give a stripy appearance. Telson and anal valves similar to body colour. Very thin black mid dorsal line. Legs and antennae pale brown. Anterior constriction almost absent, attenuation present anterior to apodous rings but not strong. Metazonal striae close, obvious and regular, vaulting barely discernable.

Eyes hardly reduced, largely readable but in one specimen difficult to distinguish rows corresponding to later stadia.

Length of legs $0.74 \mathrm{x}$ body height. Tarsus $\mathrm{L} / \mathrm{H}$ : 2.8. Length of claw $0.05 \times$ total leg. Accessory claw surpasses claw by $61 \%$.

Preanal ring with no projection, with setae dorsally (one pair), ventrally (one pair) and laterally 
12

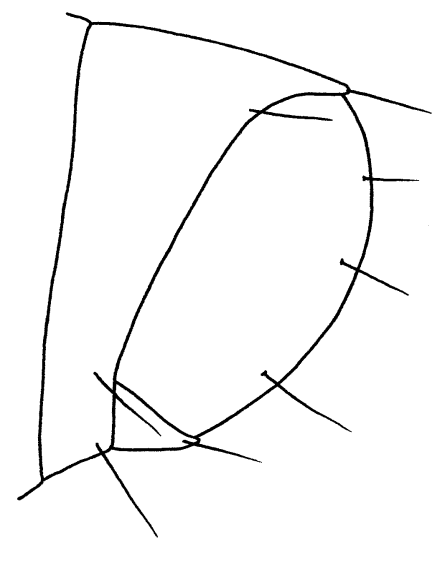

A

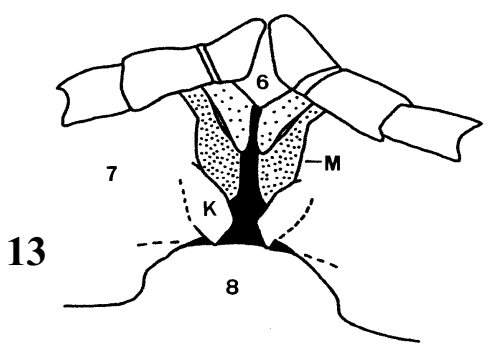

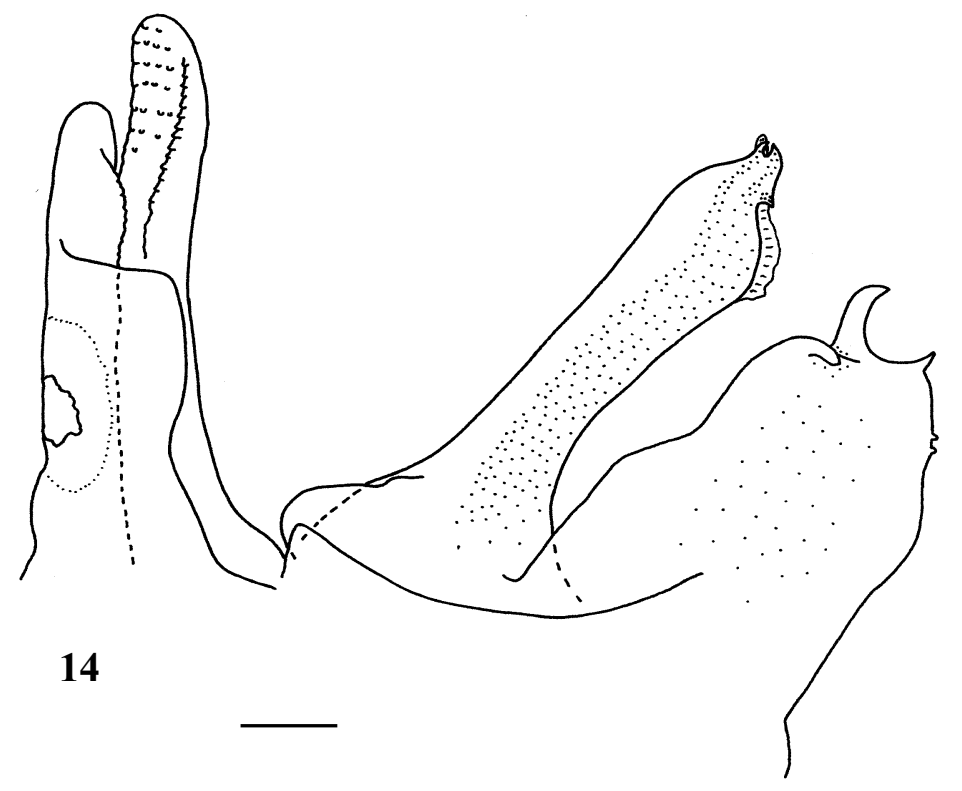

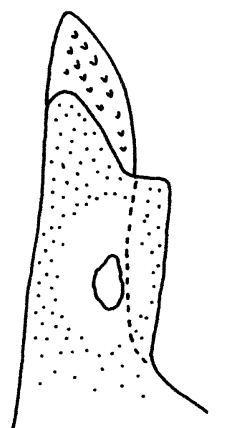

16

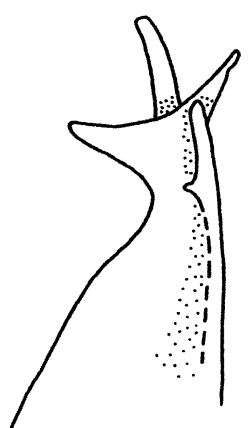

17

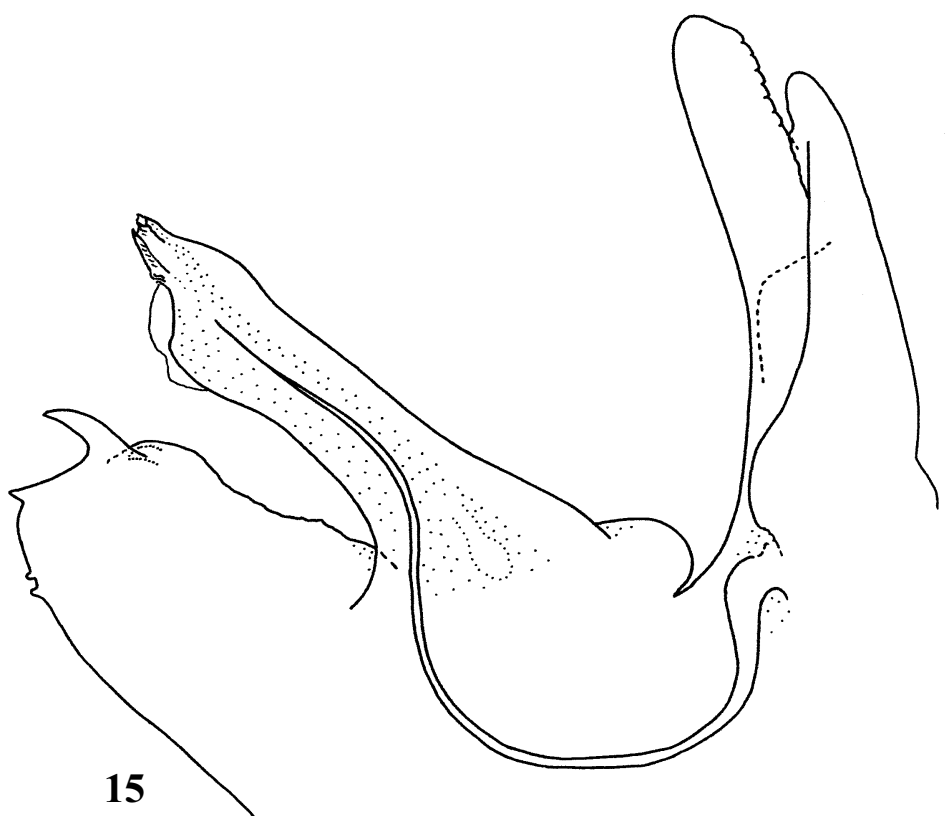

Figs. 12-17. - Cylindroiulus ventanaea, holotype male (all scale bars $=0.1 \mathrm{~mm}$ ). 12) Telson and anal valves. 13) Ventral view of ring 7 (A-anterior). 14) Right gonopods lateral view. 15) Right gonopods mesal view. 16) Right gonopods anterior view. 17) Right gonopods posterior view.

Figs. 12-17.-Cylindroiulus ventanaea, holotipo macho (barras de escala $=0,1 \mathrm{~mm}$ ). 12) Telson y valvas anales. 13) Vista ventral del segmento 7 (A-anterior). 14) Vista lateral del gonópodo derecho. 15) Vista mesal del gonópodo derecho. 16) Vista anterior del gonópodo derecho. 17) Vista posterior del gonópodo derecho.

(two pairs). Holotype with one of the lateral pairs of setae more or less ventrally. Anal valves with 3 pairs of seta. (Fig. 12).
Mandibular stipetes of mature male smoothly expanded. First pair of legs sharp hooks and ring 7 with wide triangular shaped opening, through 
which pro- and mesomerite can be seen (Fig. 13), also with small but distinct keel (flange directed ventrally). height.

Gonopods (Figs 14-17). Length $1.25 \mathrm{x}$ body

Promerite with clear lateral expansion, wrapping round the mesomerite so that from ventral view almost a tube is formed. With thin, de-sclerotised window latero-anteriorly, in the centre of which is a smaller perforation.

Mesomerite long and thin, substantially longer than promerite.

Paracoxal rim very low. Flagellum normal.

Opisthomerite simple and slender. Apically with hyaline area and various small structures at the entrance to the sperm canal.

Paracoxal process huge, with three obvious hooklike processes and several other smaller peg-like structures. Three-dimensional, with substantial region and one of the hooks extending laterally. Three-dimensional aspect most clearly seen in posterior view.

ETYMOLOGY: The name refers to the promerite and is derived from the Spanish for window.

RELATIONSHIPS WITH OTHER SPECIES: Cylindroiulus ventanaea closely resembles $C$. fenestratus, from which it differs in the more complex and threedimensional nature of the paracoxal process, details of the apex of the solenomerite, promerite and mesomerite. It also differs in lacking a telson projection.

\section{Cylindroiulus anglilectus sp. n. (Figs. 18-24)}

TYPE MATERIAL: Holotype: 1M SPAIN: Gondomar, Pontevedra Woodland S of town. $42^{\circ} 04^{\prime} 45^{\prime \prime} \mathrm{N}, 8^{\circ} 44^{\prime} 59^{\prime \prime} \mathrm{W}$. UTM 29T 0520/4658 (NG25). 24.3.04. (HR) (BMNH).

Paratypes: $13 \mathrm{M}, 6 \mathrm{~F} / \mathrm{j}(\mathrm{HR})$ details as above $(3 \mathrm{M}, 1 \mathrm{~F}$ BMNH; 3M 1F MNCN; 3M 1F MNP; 4M, 3F ZMUC) 1M, $5 \mathrm{~F} / \mathrm{j}(\mathrm{SG})(\mathrm{MNCN})$ details as above; $2 \mathrm{M}, 1 \mathrm{~F}$ (JPR) (SGMT) Details as above.

Other Material: SPAIN: As Eiras, Pontevedra, Pinewood. 41 ${ }^{\circ} 56^{\prime} 09$ 'N, 8०47'08'W. UTM 29T 0517/4642 (NG14). 25.3.04. 2M, 4F/j (PL) (MNCN).

As Eiras, Pontevedra. Alder wood. $1 \mathrm{~km}$ downstream of above locality. With garden rubbish. UTM29T 0517 4642. 4M, $1 \mathrm{jM}, 10 \mathrm{~F} / \mathrm{j}$ (SG) (MNP).

PORTUGAL: $\mathrm{Nr}$ Central de Lindoso power station, Viana do Castelo. 41 ${ }^{\circ} 51^{\prime} 34^{\prime \prime} \mathrm{N}, 8^{\circ} 16^{\prime} 26^{\prime \prime} \mathrm{W}$. UTM 29T 0560/4634 (NG63). 28.3.04. 8F/j (HR) (BMNH), 5M, 2F (SG) (ZMUC), $1 \mathrm{M}$ (JPR) (SGMT), 1M, 2F, 1jM (PL) (BMNH).

DiAGNOSIS: A medium sized and typically coloured species of Cylindroiulus. Preanal ring with a long straight pointed projection and sparse setae on the anal valves. Male cheek plate only slightly expanded and anterior gonopods protruding through an opening in ring 7. Gonopods with a thin walled promerite. Opisthomerite with a large and characteristic hooked brachite projecting mesally.

DesCRIPTION: Holotype M: Length $16 \mathrm{~mm}, \mathrm{H}$ (maximum): $1.1 \mathrm{~mm}, \mathrm{~L} / \mathrm{H} \mathrm{14.6,} 7$ rows of ocelli, $45+5$ (+ telson) body rings.

Other males: Length 15-19 mm, Height 0.9-1.3, Ocelli rows 7 (= VIII stadia) to 9 rows $(\mathrm{X})$, podous body rings $43-50$.

Other females: Maximum length 25, Maximum height 1.8. Ocelli rows up to 10 (XI stadium) and 50 body rings.

Anterior constriction slight but visible in rings 4-6, barely any attenuation except for apodous rings. Colouration generally brown, mottled prozonites, chestnut brown metazonites, darker dorsally and, in most specimens, posteriorly. Thin black, mid dorsal line, preanal ring uniform brown. Legs and antennae pale brown, some antennal segments darker apically.

Eyes normal, most with ocelli arranged in regular and 'readable' rows. Metazonites not vaulted. Striae on metazonites quite widely spaced, even and strong.

Length of legs $0.62 \mathrm{x}$ body height. Tarsus $\mathrm{L} / \mathrm{H}$ : 3.0. Length of claw 0.07 of total leg. Accessory claw surpasses claw by $10 \%$.

Preanal ring (Fig. 18) with a strong, pointed and relatively long projection dorsally; two setae on the tip of the projection, and one pair ventrally and sometimes an additional pair latero-ventrally. Subanal scale not projecting and bearing two setae. Anal valves with an obvious rim and bearing 3 (occasionally 4) pairs of setae.

Mandibular stipites of the male expanded but not greatly so (Fig. 19), first pair of legs tight hooks. Keel on ventral side of ring 7 small and short, promerites of the gonopods in many specimens clearly visible in lateral view.

Gonopods (Figs. 20-24). Length 0.85 x body height.

Promerite even and rounded, thin walled so mesomerite is clearly visible in anterior view. In no specimens examined (8) did the promerite appear actually perforate.

Flagellum present, arising almost directly from mesal side of promerite with little flange covering base.

Mesomerite triangular shaped in anterior view, much shorter than promerite and narrow.

Paracoxal process sharply pointed, paracoxal rim low.

Graellsia, 63(2), Diciembre 2007, pp. 279-294 - ISSN: 0367-5041 

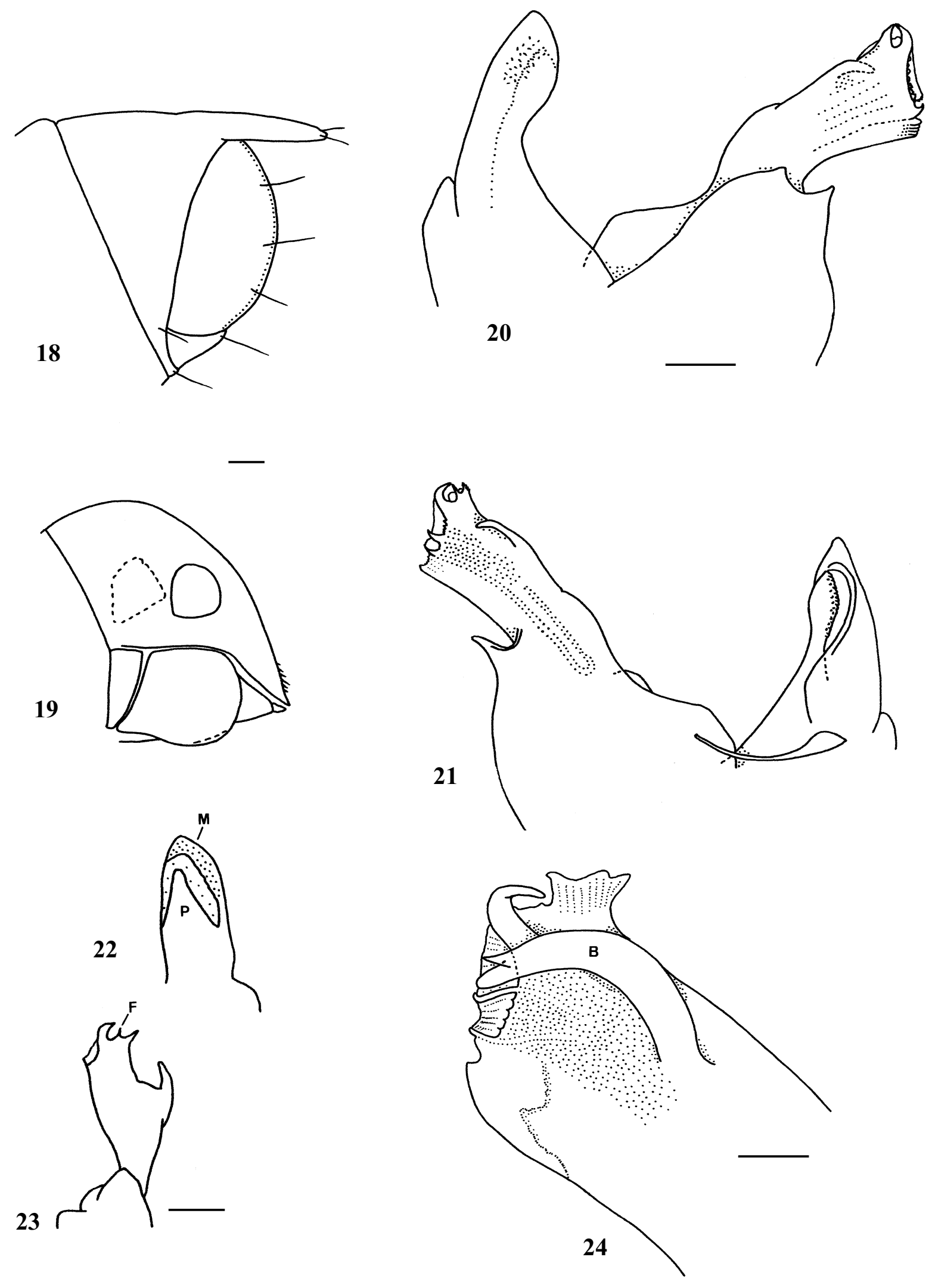

Graellsia, 63(2), Diciembre 2007, pp. 279-294 — ISSN: 0367-5041 


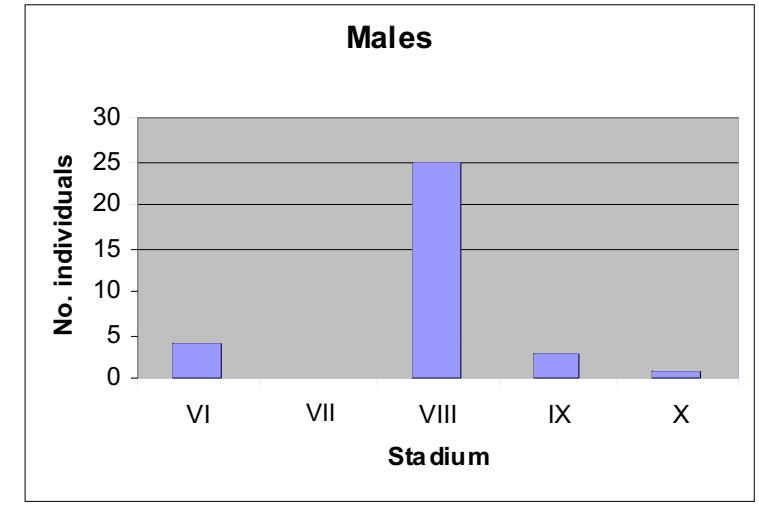

Fig. 25.- Stadial spectra for male C. anglilectus in March 2004.

Fig. 25.- Espectro de estadios de desarrollo para machos de C. anglilectus en marzo de 2004.

Opisthomerite simple in shape with various small projections apically including one hook-shaped apically and angled anteriorly. A much larger hook-shaped brachite, arising $1 / 3$ of the distance from the apex of the opisthomerite on the mesal surface and directed dorsally. In most specimens this is not long enough to reach the tip of the opisthomerite but in a least one (Fig. 24) it does.

Etymology: The name means 'found by English'.

RELATIONSHIPS WITH OTHER SPECIES: Cylindroiulus anglilectus shows strong resemblances to C. perforatus Verhoeff, 1905 and C. fenestratus both from the same geographical area. The thin promerite, allowing the mesomerite to be visible through it and the simple opisthomerite are similar in all three species. Cylindroiulus anglilectus differs from C. perforatus in the presence of a projection on the telson and from $C$. fenestratus in the small and simple paracoxal process. It differs from both in the short mesomerite and the large hook

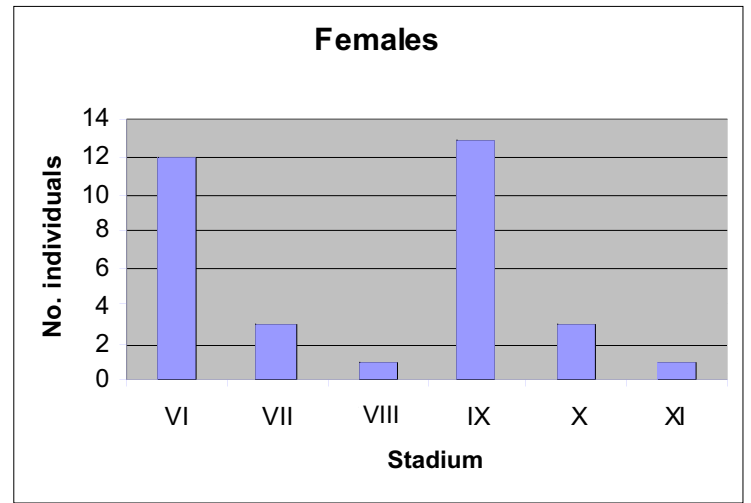

Fig. 26. - Stadial spectra for females C. anglilectus in March 2004

Fig. 26.- Espectro de estadios de desarrollo para hembras de C. anglilectus en marzo de 2004.

shaped brachite on the mesal surface of the opisthomerite.

LIFE CYCLE: As there are 70 individuals of this species, all collected within a one week period, it is possible to make some comments about the life cycle by looking at the stadial spectrum. Figs. 25 and 26 illustrate the numbers of individuals in each stadium for both males and females. That for the males is striking for the large number of individuals in stadium VIII and only a very small number in older stadia; all those in stadium VI were immature, all those in the older stadia are mature. The females show the same pattern but slightly less extreme and with the peak one stadium later at IX. These figures suggest that both sexes are semelparous, reaching maturity, reproducing and then not surviving to breed in future years. Although most individuals mature in the same stadia (VIII for males and IX for females) maturation is delayed by one or two stadia in a few individuals. The graph for the females has

Figs. 18-24.- Cylindroiulus anglilectus, figs. 18-23 holotype male (all scale bars $=0.1 \mathrm{~mm}$ ). 18) Telson and anal valves. 19) Head showing poorly expanded stipetes. 20) Right gonopods lateral view. 21) Right gonopods mesal view. 22) Right gonopods anterior view. 23) Right gonopods posterior view. 24) Right gonopods of a male from As Eiras showing detail of the opisthomerite tip in mesal view. Note the length of the brachite. (Scale bar $=0.04 \mathrm{~mm}$ ).

Figs. 18-24.- Cylindroiulus anglilectus, figs. 18-23 holotipo macho (barras de escala =0,1 mm). 18) Telson y valvas anales. 19) Cabeza mostrando estipetes pobremente expandidos. 20) Vista lateral del gonópodo derecho. 21) Vista mesal del gonópodo derecho. 22) Vista anterior del gonópodo derecho. 23) Vista posterior del gonópodo derecho. 24) Gonópodo derecho de un macho de As Eiras, mostrando detalles del extremo del opistomerito en vista mesal. Nótese la longitud de la braquita. (Barra de escala $=0,04 \mathrm{~mm}$ ). 
two distinct peaks so it seems likely that this species has a two year life cycle; individuals reaching stadium VI in the first year and then maturing the following year. This pattern is very similar to that recorded for C. gemellus Enghoff, 1982, in Madeira (Read, 1988).

\section{Relationships between the new species and others previously described}

All of the new species can be considered as falling within the poorly defined subgenus Aneuloboiulus, along with the Cylindroiulus species swarm from the Madeiran archipelago. The relatively simple structure of the male gonopods seen in the species described here is also found in many of the Madeiran ones. They all differ from the Madeiran species however, in having the preanal ring with only a small number of setae and not a subcomplete ring. Despite this some of these species still are the most likely candidates for being a sister group to the madeirae group (Read 1989a, Enghoff, 1992).

A notable feature of two of the species in the perforatus group is the very large paracoxal process, although this may be expanded in other species it is rarely as angular and never angular with associated projections, however this character is not shared by $C$. perforatus which has a very 'normal' paracoxal process.

It is clear that the systematics in the Aneuloboiulus subgenus requires considerably more comparative work in order to elucidate further the relations within it and between species groups from other subgenera. As yet there still no clear apomorphy for the group, which may eventually prove to be a 'rag-bag' of different forms.

\section{The Cylindroiulus truncorum group}

Cylindroiulus truncorum (Silvestri, 1896)

PORTUGAL: Britelo, Viana do Castelo. Roadside scrub \& woodland. 41 ${ }^{\circ} 49^{\prime} 42^{\prime} \mathrm{N}, 8^{\circ} 18^{\prime} 31^{\prime \prime} \mathrm{W}$, UTM 29T 0557/4631 (NG53), 28.3.04. 1M (DK).

This species has not previously been found on the Iberian peninsular but is known from Madeira and the Canary Islands. Schubart (1934) regarded C. truncorum as a north African species that was introduced into Europe and it is synanthropic in northern Europe, however the find here suggests that it is just as likely to be an Iberian species.

\section{Cylindroiulus species from other subgenera/groups}

The following species cannot be assigned species groups or subgenera without further study.

\section{Cylindroiulus propinquus (Porat, 1840)}

PORTUGAL: Vascões, Viana do Castelo, Oakwood, 4153'29”'N, 8³0'37'W, UTM 29T 0540/4638 (NG43), 28.3.04. 1M (HJR).

$\mathrm{Nr}$ Central de Lindoso power station, Viana do Castelo, 4151'34”N, 816'26”W, UTM 29T 0560/4634 (NG63), 28.3.04. 1M (HJR) 1M, 2F (DK).

Cylindroiulus propinquus was previously considered to belong to a separate genus, Micromastigoiulus Verhoeff, 1899, on account of its much reduced flagellum. This was not considered a great enough difference to justify a separate genus by Read (1990) because reduction of the flagellum arises frequently in the Julidae.

This species has previously been found in Madeira, the Azores and mainland Portugal (Enghoff, 1982).

\section{Cylindroiulus dahli Demange, 1970}

SPAIN: A Coruna, Praia Riocobo, S of Punta, Roncudo shore. UTM29T(NH09), 27.ii.1993. 2M, 1F (DB) (MNCN).

Oia, Pontevedra Province, Km post 36 on road PO552. 41'59'17'N, 8053'01'W. UTM 29T 0509/4648 (NG04). 24.3.04. 1M, 1F (SG) (SGMT).

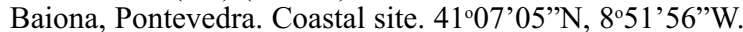
UTM 29T. 0511/4663 (NG16). 24.3.04. 1M, 1F, 1j (SG) (ZMUC), 2M, 1F (PL) (BMNH), 2M, 1F (DK) (MNP).

Finca Rio Miño. 25.3.04. 17M (SG) (ZMUC) 1M (PL) (MNCN).

Beade, Orense. Oakwood with chestnut \& pine. 42 20 '27'N, $8^{\circ} 08^{\prime} 15^{\prime \prime} \mathrm{W}$. UTM 29T 0571/4688 (NG78). 26.3.04. 1M, 1F (SG) (MNP).

Camposancos, nr. La Guardia (A Guarda), Pontevedra. 41 53 '43”N, 851'55”W, UTM 29T 0511/4638 (NG13). 29.3.04. 2M, 2F (SG) (BMNH).

A Coruna, Cabo Vilan, $3 \mathrm{~km} \mathrm{NW}$ of Camarinas. Supra littoral. UTM29T(MH87), 2.iii.1993. 1M, 1F (DB) (MNCN).

This species was previously considered to be endemic to the Azores (Demange, 1970; Enghoff, 1992) and has not previously been recorded from the European mainland. As a result of this collection it is now known from seven locations in Spain. The habitats ranged from oak woodland to coastal areas but several locations were human influenced, for example the garden of a Finca where the group was staying and Camposancos, a prominent hill with an archaeological site on top. It seems likely that this species was transported to the Azores, at least partly due to its preference for living in proximity to human habitation and it is interesting that three localities are coastal. There 
are two further interesting features of these collections. First, the collection from Finca Rio Miño contains 18 individuals but all are mature males and secondly, one of these males has fully developed gonopods but the first pair of legs are normal walking legs (as would be expected in a female) and the cheek plate is only expanded a very small amount, not to the same extent as the other mature males. It was not dissected to see if there were vulvae present.

\section{Cylindroiulus sanctimichaelis Attems, 1927 / caeruleo- cinctus (Wood, 1864)}

SPAIN: Limestone plateau N. of Ebro Gorge, on Madrid Santander Road (Burgos), UTM30T(VN35), 10.v.1990. 1M, 4F (DB).

Despite the presence of a mature male in this sample it proved impossible to identify the specimens to species level although it is clearly in the C. londinensis (Leach, 1815) group (although the complete absence of a telson projection suggests not $C$. londinensis itself). The $C$. londinensis group is here taken to include $C$. londinensis, $C$. caeruleocinctus, C. finitimus (Ribaut, 1905) and C. sanctimichaelis and perhaps also $C$. ibericus Brölemann, 1913. These species are difficult to separate, see Mauriès (1964), Blower (1985) and Vicente (1981) for more details. On the basis of current known distributions $C$. caeruleocinctus is perhaps more likely as it has a mainly Atlantic distribution; $C$. sancti-michaelis seems to be a species from the drier south and east parts of the Iberian pensinsula (Cataluna, Castilla and Andalucia). This group in Iberia would benefit from further study and more specimens from other areas would be helpful.

\section{Key to species}

The following key covers species of Cylindroiulus known to occur in north west Iberia and those previously recorded from elsewhere on the peninsular that might reasonably be expected to be found there (according to current known distributions).

1. Blind, totally lacking ocelli ….......................... gregoryi With ocelli ............................................................... 2

2. Subanal scale projecting, at least not lying flat to the edge of the anal valves ........................................................ 3 Subanal scale closely adpressed to the ventral edge of the anal valves
3. Opisthomerite of gonopods squat and broad; flagellum of normal length; subanal scale very long pyrenaicus (Brölemann, 1897) Opisthomerite of gonopods 'normal', i.e. not squat and broad, but with small spines on dorsal edge; flagellum reduced in length; subanal scale of normal length

propinquus

4. Telson with projection, either pointed or blunt, extending well beyond the posterior limit of the anal valves ........ 5 Telson may be slightly protruding but does not clearly extend beyond the posterior limit of the anal valves .... 9

5. Telson projection clearly club-shaped, wider at the apex than at the point of arising from the body ring; gonopods with long, thin and hook-shaped paracoxal process almost as long as opisthomerite ..................... punctatus Telson pointed or blunt but not club-shaped; paracoxal process poorly developed, 'normal' or if large then also broad, not thin and with hook at tip ................................. 6

6. Paracoxal process large, broad and with projections apically, promerite with perforation .................. fenestratus Paracoxal process small or almost absent, promerite without perforation but may have a transparent region .... 7

7. Paracoxal process almost lacking; opisthomerite long, narrower at the mid point than apically; paracoxal process blunt ended ............. sagittarius (Brölemann, 1897) Paracoxal process clearly present, though not large; opisthomerite parallel sided or broader apically than at the mid point; telson projection sharply pointed or gently rounded

8. Promerite with transparent region; opisthomerite narrow, with hook-shaped brachite arising from the mesal surface and other apparent projections apically ........ anglilectus Promerite opaque; opisthomerite broader, with a single projection apically boreoibericus

9. Promerite with transparent region or perforation ....... 10 Promerite opaque, with no transparent region ............ 11

10. Paracoxal process broad and angular, with several pointed projections apically ................................. ventanaea Paracoxal process smoothly rounded, ending in a single point apically perforatus

11. Brachite very large, smoothly expanded, extending beyond the apex of the solenomerite; may also have large phylacum, generally large sized animals (over $20 \mathrm{~mm}$ ) and usually blackish in colour .......... londinensis group I.e. londinensis, caeruleocinctus, finitimus and sanctimichaelis and C. ibericus see Blower (1985) and Vicente (1981) for details and note that $C$. londinensis has a very short but distinct, telson projection.

Brachite, if present, not large and not extending beyond the apex of the solenomerite; small sized animals (less than $20 \mathrm{~mm}$ ), either brown or blackish 12

12. Paracoxal process sharply pointed, pro- and mesomerite short and squat looking; anal valves with more than 7 setae each truncorum Paracoxal process absent, or if present not sharply pointed, pro- and mesomerite short and squat or more elongate; anal valves usually with fewer than 7 setae each .......... 13 
13. Paracoxal process large and angular, with almost horizontal ventral edge; promerite hook tipped in lateral view; animals dark brown to black in colour ........ dahli Paracoxal process poorly defined and linked to opisthomerite; promerite simple; animals brown to darker brown in colour, 3 setae on each anal valve 14

14. End of opisthomerite with finger-shaped projection; mesomerite shorter than promerite .............. britannicus End of promerite without finger-shaped projection; mesomerite and promerite roughly the same length

latestriatus

Note: these two species are hard to separate but the gonopods of each have been well illustrated, see for example Blower (1985).

\section{Concluding comments}

Cylindroiulus continues to be a genus of millipedes which, despite outward appearances of uniformity, continues to yield remarkable numbers of species. That several new species have been found during the course of a fairly limited amount of collecting in one relatively small part of the Iberian peninsula indicates the potential for other areas. This small collection has also strengthened the links between the faunas of the mainland Iberian peninsular and the mid Atlantic islands of the Azores, Madeira, and the Canaries regarding this genus. The finds of C. britannicus and C. truncorum on the mainland are considered by Kime (pers. comm, 2007) to be very significant and strengthen the idea that the Iberian peninsula was an important glacial refuge for some of these species.

\section{ACKNOWLEDGEMENTS}

Most of the millipedes included here were collected during a British Myriapod \& Isopod Group field visit. I am grateful to all those that took part and who allowed me to study their specimens, especially Paul Lee who organised the trip. David Bilton enabled me to include specimens collected by him from the same area for which I express my thanks. Henrik Enghoff commented on drafts of the text and also made some suggestions regarding species names; Desmond Kime helped by providing information on species distribution, answered numerous other queries and commented on the text, I am very grateful to both gentlemen. I am also thankful to Arturo Elosegi who made the Spanish translations.

\section{References}

ATtEMS, C., 1927. Über palaearktische Diplopoden. Archive für Naturgeschichte, 1: 114-256.
AtTems, C., 1927. Myriapoden aus dem nördlichen und östlichen Spanien, gesammelt von Dr. F. Haas in den Jahren 1914-1919. Abhandlungen der Senckenbergischen Naturforschenden Gesellschaft. Frankfurt a.M., 39(3): 235-289.

Blower, J. G., 1985. Millipedes. Linnaen Society Synopses of the British fauna (New series) No. 35. E.J. Brill/Dr.W. Backhuys. London. 242 pp.

Demange, J.-M., 1970. Myriapodes de Madère et des Açores. Boletim do Museu municipal do Funchal, 25(107): 5-43.

Enghoff, H., 1982. The millipede genus Cylindroiulus on Madeira - an insular species swarm (Diplopoda, Julidae). Entomologica Scandinavica Supplement, 18: 1-142.

ENGHOFF, H., 1992. Macaronesian millipedes (Diplopoda) with emphasis on endemic species swarms on Madeira and the Canary Islands. Biological Journal of the Linnean Society, 46: 153-161.

Enghoff, H. \& Kime, R. D., 2004. Fauna Europaea: Fauna Europaea: Diplopoda. - Fauna Europaea version 1.1, http: //www.faunaeur.org [version 1.2: 2005].

KIME, R. D., 1999. The continental distribution of British and Irish millipedes. Bulletin of the British Myriapod \& Isopod Group, 15: 33-76.

Korsós, Z. \& Enghoff, H., 1990. The Cylindroiulus truncorum group (Diplopoda: Julidae). Entomologica Scandinavica, 21: 345-360.

LEE, P., 2004. Expedition to Galicia - a preliminary millipede report. British Myriapod \& Isopod Group Newletter, 9: 3.

MAuRiès, J. P., 1964. Notes sur les Diplopodes Pyrénéns. 1. Les Cylindroiulus du sous-genre Bracheoiulus Verhoeff. Bulletin de la Société d'Histoire Naturelle de Toulouse, 99(3-4): 444-449.

MAuriès, J. P., 2005. Essaie de classification des Glomerida (Diplopoda), et description de deux nouveaux genres du nord-ouest de la péninsule ibérique. Arthropoda Selecta, 14(3): 241-249.

READ, H. J., 1988. The life histories of millipedes: A review of those found in British species of the order Julida and comments on endemic Madeiran Cylindroiulus species. Revue d'Écologie et de Biologie du Sol, 25(4): 451-467.

READ, H. J., 1989a. New species and records of the Cylindroiulus madeirae-group, with notes on phylogenetic relationships (Diplopoda, Julida: Julidae). Entomologica Scandinavica, 19: 333-347.

READ, H. J., 1989b. The Cylindroiulus perforatus-group, with the description of a new species and notes on variation within $C$. perforatus Verhoeff, 1905 (Diplopoda, Julida: Julidae). Entomologica Scandinavica, 20: 243-249. 
READ, H. J., 1990. The generic composition and relationships of the Cylindroiulini - a cladistic analysis (Diplopoda, Julida: Julidae). Entomologica Scandinavica, 21: 97-112.

READ, H. J., 1992. The genus Cylindroiulus Verhoeff, 1894 in the faunas of the Caucasus, Turkey and Iran (Myriapoda: Diplopoda: Julidae). Senckenbergiana Biologica, 72(4/6): 373-433.

READ, H. J., 2005. A revision of the Cylindroiulus distinctus Lucas group from north Africa with descriptions of six new species (Diplopoda, Julida, Julidae). Journal of Natural History, 39(18): 1491-1532.

SCHUBART, O., 1934. Tausendfüssler oder Myriapoda. 1. Diplopoda. Die Tierwelt Deutschlands, 28: 1-318.
VerhoefF, K. W., 1930. Über Diplopoden aus Italien, namentlich Piemont. Zoologische Jahrbücher, Abteiling für Systematik, 59: 587-446.

Vicente, M. C., 1985. Diplopódos epigeos de Cataluña II (Iúlidos). Eos, 61(1-4): 321-350.
Recibido, 23-IV-2007

Aceptado, 25-X-2007

Publicado, 27-XII-2007 
Appendix 1.- Cylindroiulus species from the Iberian peninsula, not including species only found on offshore islands (based on information from Enghoff \& Kime, 2004 and Kime, pers. comm. 2006).

Apéndice 1.- Especies de Cylindroiulus de la península Ibérica; no se incluyen las especies encontradas únicamente en islas situadas a poca distancia de la costa (basado en información de Enghoff \& Kime, 2004 y Kime, pers. comm. 2006).

\begin{tabular}{|c|c|c|c|c|c|c|c|}
\hline Species & Authority & Mainland Spain & $\begin{array}{l}\text { Mainland } \\
\text { Portugal }\end{array}$ & Azores & Madeira & Canaries & NW Iberia \\
\hline anglilectus & Read, 2007 & Galicia* & $\mathrm{Y}^{*}$ & & & & $\mathrm{Y}$ \\
\hline britannicus & (Verhoeff, 1891) & Galicia* & $\mathrm{Y}^{*}$ & $\mathrm{Y}$ & $\mathrm{Y}$ & $\mathrm{Y}$ & $\mathrm{Y}$ \\
\hline boreoibericus & Read, 2007 & Galicia* & $\mathrm{Y}^{*}$ & & & & $\mathrm{Y}$ \\
\hline caeruleocinctus & (Wood, 1864) & Aragon & $\mathrm{Y}$ & & & & $\mathrm{Y}$ \\
\hline chalandei & (Ribaut, 1904) & Pyrenees, Cataluna & & & & & \\
\hline dahli & Demange, 1970 & Galicia* & & $\mathrm{Y}$ & & & $\mathrm{Y}$ \\
\hline fenestratus & Read, 1989 & Galicia* & $\mathrm{Y}$ & & & & $\mathrm{Y}$ \\
\hline finitimus & (Ribaut, 1905) & Pyrenees & & & & & \\
\hline franzi & Attems, 1952 & Andalucia & & & & & \\
\hline gregoryi & Read, 2007 & Galicia* & & & & & $\mathrm{Y}$ \\
\hline ibericus & Brölemann, 1913 & Pyrenees & & & & & \\
\hline iluronensis & Brölemann, 1912 & Pyrenees & & & & & \\
\hline latestriatus & (Curtis, 1845) & Galicia, Cantabrica & $\mathrm{Y}$ & $\mathrm{Y}$ & & $\mathrm{Y}$ & $\mathrm{Y}$ \\
\hline londinensis & (Leach, 1815) & NE west to Vizcaya & & & & & $?$ \\
\hline propinquus & (Porat, 1840) & & $\mathrm{Y}$ & $\mathrm{Y}$ & $\mathrm{Y}$ & & $\mathrm{Y}$ \\
\hline punctatus & (Leach, 1815) & $\begin{array}{l}\text { Pyrenees, Catalunia } \\
\text { west to Cantabrica }\end{array}$ & & & & & Y \\
\hline pyrenaicus & (Brölemann, 1897) & Pyrenees, west to Vizcaya & & & & & Y? \\
\hline sagittarius & (Brölemann, 1897) & Pyrenees, west to Asturias & & & & & Y \\
\hline sanctimichaelis & Attems, 1927 & Catalunia, Castilla, Andalucia & & & & & Y \\
\hline truncorum & (Silvestri, 1896) & & $\mathrm{Y}^{*}$ & & Y & Y & Y \\
\hline unciger & Attems, 1952 & Madrid & & & & & \\
\hline ventanaea & Read, 2007 & Galicia* & & & & & \\
\hline
\end{tabular}

* Results of present study 